\title{
The Education Reform of Business Students Under the "Internet Plus" Business Model Transformation Trend
}

\begin{abstract}
Xiaolei Zhang*
School of International Trade and Business, Nanjing University of Finance and Economics, Jinan 250353, Shandong Province, China

*Corresponding author: Xiaolei Zhang, zhangxiaolei0824@126.com

Abstract: The "Internet Plus" business model calls for the optimization of business education in higher education institutes. The fast pace of "Internet Plus" requires business students to have abundant interdisciplinary knowledge, comprehensive modern business skills, habits of lifelong self-learning, and the courage to innovate. This paper proposes that higher education institutes should improve their business education programs in the following ways: firstly, form teaching alliances to provide interdisciplinary learning opportunities for business students; secondly, establish a social practice tutor team from excellent alumni; thirdly, build an online education platform for alumni to develop lifelong autonomous learning habits; finally, explore the three-tutor training model for business students.
\end{abstract}

Keywords: Internet Plus; Business education; Higher education reform

Publication date: November 2021; Online publication: November 30, 2021

\section{Introduction}

The 47th Statistical Report on China's Internet Development, released by China Internet Network Information Center, showed that the number of internet users in China had reached 989 million and the internet penetration rate was $70.4 \%$ by December 2020 . With the rapid development of the internet industry, it has become a pioneer leading the wave of changes in China's economic structure and quality in the new era. Not only is the internet industry itself absorbing and accommodating social cutting-edge technologies with unprecedented efficiency, but it is also driving traditional manufacturing, service, and other surrounding industries to closely combine their own advantages with the internet, in order to hitch the ride of the internet revolution. Under this background, the "Internet Plus" business model came into being in China. As early as March 2015, Premier Li Keqiang proposed for the first time in the Report on the Work of the Government at the 12th National People's Congress, "Formulate an 'Internet Plus' action plan to promote the integration of mobile internet, cloud computing, big data, internet of things, and modern manufacturing industry, as well as promote the healthy development of e-commerce, industrial internet, and internet finance." Premier Li Keqiang's proposal marked the rising of "Internet Plus" as a national strategy. In the following annual report on the central government's work, the "Internet Plus" business model transformation of traditional manufacturing and service industries has always been one of the core development goals.

\section{New features of the "Internet Plus" business model}

Conceptually, the "Internet Plus" business model is based on the internet as a platform, using modern 
information and communication technology to integrate with other industries, in order to create new products, develop new business model, and ultimately build a new business ecosystem, which connects everything based on the internet ${ }^{[1]}$. The core of the "Internet Plus" business model is cross-border integration. The advantages of the ultra-low cost of information acquisition brought by the internet technology revolution are applied to the production and service processes of various industries and gradually transform all industries into an information intensive industry, so as to realize the pan data of economic activity and the networking of social life. Through deep integration with the internet, traditional industries can accurately predict market trends, carry out forward-looking research and development (R\&D) ${ }^{[2]}$, and interact directly with users ${ }^{[3]}$. Compared with traditional business models, the "Internet Plus" business model has two new characteristics.

\subsection{Cross-border integration}

Under the "Internet Plus" business model transformation trend, the cross-border integration of traditional industries and the internet has created a number of new industries and commercial forms. For example, the integration of the catering industry and the internet has spawned many new commercial forms, such as group-buying and takeout apps as exemplified by Pinduoduo and Eleme. The integration of the taxi industry and the internet gave birth to a new model of online car hailing, such as Uber and DiDi. Cross-border integration is the soul of "Internet Plus." From the current development trend of the industry, there are two developing directions in the cross-border integration of the business model: on the one hand, internet companies vertically integrate their upstream and downstream industrial chains to enhance power control over the entire industrial chain, such as video websites investing in film and television companies as well as strengthening the control over upstream content supply; on the other hand, internet companies have made "Internet Plus" transformation in other industries with the help of their huge user resources, such as the integration of Ant Group and Hangzhou municipal services as well as the cooperation between WeDoctor and traditional hospitals.

\subsection{Fast-paced innovation}

The "Internet Plus" business model has made unprecedented improvements in the speed of enterprise innovation. Internet companies can rely on huge user resources, strong financial strength, accurate data analysis, and forecasting capabilities to help traditional industries receive all-round support from financing, business operations, to product and service marketing. This would greatly shorten the time required for an "innovative business idea" from birth to implementation. For example, relying on its deep-rooted internet marketing thinking, the famous unicorn enterprise, Luckin Coffee, has successfully achieved the rapid growth of valuation from 0 to more than US \$1 billion only in eight months. Therefore, with the blessing of the internet, if enterprises desire to succeed in the fierce market competition, they should not only compete for the quality of innovation, but also to pay more attention to the efficiency and speed of innovation, especially in industries with low technology and capital threshold. If the innovative ideas of an enterprise are a little slower in the implementation process, other industries may take the lead.

\section{New requirements for business students under the "Internet Plus" trend}

The new characteristics of the "Internet Plus" business model demand a higher requirement for business students. Compared with the traditional business model with relatively slow pace of change, the "Internet Plus" business model requires more interdisciplinary knowledge, divergent thinking, cross-border skills, and flexible personality from business students. 


\subsection{Rich interdisciplinary knowledge}

On the basis of a high-level professional knowledge in economics and management, business students should also have basic understanding of the industrial characteristics and development trends of the internet technology, general industry, agriculture, and service industry, in order to break the knowledge barriers among different disciplines and achieve the integration of multi-disciplinary knowledge. This is the necessary basis for business students to transform the traditional business model and improve the operation efficiency of enterprises with the help of modern internet tools.

\subsection{Comprehensive modern business skills}

In the "Internet Plus" business trend, the renewal speed of the employee team structure for ordinary enterprises would obviously lag behind the updating speed of market trends. This requires business students to cater to the market and their occupation needs as well as adjust their professional roles in real time. In general, business students should have a high level of teamwork, innovative thinking, data analysis skills, aesthetic design capability, public relation skills, etc. ${ }^{[4]}$.

\subsection{Lifelong autonomous learning habit}

The high intensity of work pressure brought by the internet has made it impossible for businessmen to enroll in formal MBA (Master of Business Administration) programs. This requires businessmen to learn the methods of autonomous learning during their college years and develop good autonomous learning habits, so as to adhere to autonomous learning while working and continuously expand their knowledge system, in order to deal with unpredictable changes in the external environment.

\subsection{Innovative thinking skills}

In the era of internet economy, innovation is not only the responsibility of full-time technical $R \& D$ personnel or enterprise managers, but it requires all employees of an enterprise to join in and contribute their talents and hard work. The speed and diversity of innovation are no less important than the quality of innovation in the "Internet Plus" business model. The traditional business model emphasizes more on the cultivation of "great innovation achievements" and hopes to change the fate of enterprises with major technological innovation or business model innovation. However, this only applies to enterprises with deep pockets. Small and micro businesses can also succeed in the "Internet Plus" business model if they explore unique innovative ideas in small areas as they are able to quickly carry out their innovative ideas with the help of internet channels. 


\section{Main problems of the traditional business education in China}

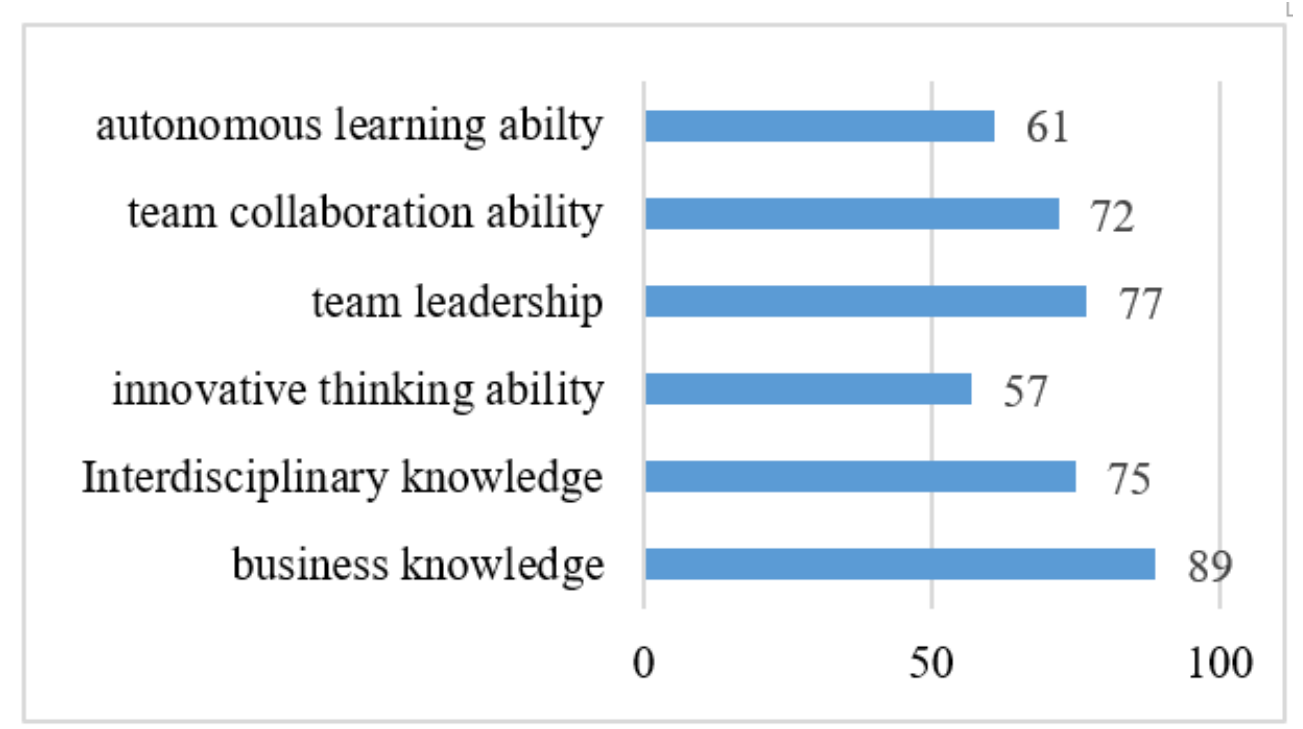

Figure 1. Evaluation of fresh business graduates by employers

The full score of all "abilities" is 100; the data in the figure is the average score of 104 respondents. Through telephone, e-mail, and WeChat interview with 104 professionals from human resource departments of internet enterprises in Nanjing China, information pertaining to the evaluation of the ability of fresh graduates in business related majors has been obtained (Figure 1). According to the statistics shown in Figure 1, this article summarizes four common problems of business education in China.

\subsection{Inadequate interdisciplinary comprehensive knowledge reserve of business students}

Traditional business courses in China mainly focus on learning the theoretical knowledge of economics and management rather than the training of practical skills and the expansion of courses in other disciplines. This directly leads to the lack of knowledge about internet technology and the development of modern manufacturing, agriculture, and commerce industries. It is difficult to adapt to the demand of enterprises for a comprehensive interdisciplinary knowledge reserve among business talents in the era of "Internet Plus." In comprehensive universities, business students can make up for this problem to a certain extent through minor and elective courses, but in professional financial colleges, this problem has not been solved effectively.

\subsection{Business students' teamwork and leadership skills are not fully exercised}

The one-child policy ensues a poor training environment for students to develop peer cooperation while growing within their family environment ${ }^{[5]}$. Hence, it is important for higher education institutions to strengthen the cultivation of students' teamwork and leadership skills. At present, China's higher education institutions generally hope that students can consciously exercise their communication, teamwork, and leadership skills by participating in student organizations, such as after-school associations. However, students only hope to polish their resumes by joining these associations. Simple formalistic community activities would not help achieve the goal of building team cooperation and leadership skills. In the long run, business graduates would naturally find it difficult to adapt to various roles in the real business world, such as leaders, colleagues, subordinates, and customers. 


\subsection{Exam-oriented education breeds weariness in self-learning}

China's current higher education for business still shows typical exam-oriented characteristics. For business students, the ultimate purpose of learning is to pass the curriculum exams, vocational certificate examination, and graduate entrance examination. This exam-oriented learning inevitably drives teachers to adopt the cramming style teaching method, in order to ensure students would obtain high scores with the highest efficiency. Business students commonly indulge in rote learning in universities, transforming them into "memory machines." This also breeds weariness among students, which is not conducive to developing their long-term and sustainable autonomous learning habits. In addition, the professional knowledge learned by business students through rote learning is updated very quickly in the internet era. Upon graduation, the knowledge learned is already outdated. If they lack the interest and habit of long-term independent learning, they would not be able to meet the employment needs for business talents in the internet era.

\subsection{Restricted conditions for business students to cultivate innovative thinking}

At present, higher education institutions in China generally pay more attention to academic innovation than practical innovation, which is unfavorable to the cultivation of innovative thinking skills among business students. From the perspective of innovation methods, business innovation to a large extent depends on summarizing problems and experiences in business practice as well as exploring new methods to break through the bottleneck in the existing business model, which requires business students not only to have a good business theoretical basis, but also sufficient social practice opportunities to stimulate innovative thinking in practice. However, at present, although universities in China have built a number of practice bases in cooperation with enterprises for business students and require students to complete summer social practice as well as earn graduation social practice credits, there is a lack of quality supervision in the social practice of business students based on the teaching evaluation set by the education administrative department. As a result, the social practice bases usually cannot provide high-quality practical teaching services for business students.

\section{Conclusion}

\subsection{Form teaching alliances to promote interdisciplinary courses}

China's education administrative department should pay more attention to the exchange programs among domestic universities and guide universities to make full use of the advantageous resources of domestic peers to form teaching alliances and complement each other. At present, C9 University Alliance, Excellent University Alliance, G7 University Alliance, and Z14 University Alliance among China's well-known universities have explored a relatively mature cooperation mode, which should be extended to more ordinary universities with the support of the education administrative department. Besides, the enrichment of mobile internet teaching resources, such as massive open online courses (MOOCs), interuniversity temporary employment of teachers, and interuniversity purchase of mobile internet teaching resources are also optional ways for universities to improve their own teaching resources. For example, financial universities in China can promote the mutual sharing of internet teaching resources with adjacent universities, such as science and technology, normal education, medicine and art, so as to provide business students with opportunities to learn more professional knowledge from other industries.

\subsection{Establish a social practice tutor team comprising of excellent alumni}

Higher education institutions in China should combine the construction of students' social practice platform with the construction of a high-level social practice tutor team, provide planning, guidance, supervision, and evaluation services for students' social practice, in order to strengthen the training of innovative 
thinking for business students. In terms of the sources of social practice tutors, universities should make full use of their high-quality alumni resources in the local business community, employ excellent alumni as social practice tutors, as well as establish a diversified and huge social practice tutor team ${ }^{[6]}$. On the one hand, this can directly solve the problem of shortage of social practice opportunities for business students, and on the other hand, it can further stabilize and expand the social influence of universities in the local business community, so as to truly make business research serve business practices.

\subsection{Build an online education platform for alumni}

Business education in China's universities should make use of the online teaching platform to create a membership platform for their school alumni in promoting lifelong learning and guide business graduates to form a good habit of lifelong autonomous learning. Business graduate resources are important strategic assets for the construction of business schools. Excellent graduates should be encouraged to become social mentors for students' practical education. By launching lifelong learning online education platforms for business schools' alumni, it could surely provide graduates with real-time updated knowledge and skill training services to help them improve their vocational skills. Besides, it is also conducive to attracting excellent alumni to repay their alma mater and form a healthy interactive relationship between universities and their graduates.

\subsection{Explore the three-tutor training model}

Business schools in China should learn from the training model of professional master's degree programs. At present, China's excellent professional master's degree programs are under a double-tutor training model, comprising of university professors and enterprise experts. Business schools should upgrade this doubletutor training model into a three-tutor model, comprising of business school professors, other industry school professors, and enterprise management or technical experts. On the one hand, the diversified team of tutors provides convenience for students to integrate business knowledge with the business practice of a specific industry at the learning stage, so as to cultivate their cross-border innovation skills. On the other hand, special training programs can also be customized for each student according to their specific conditions, so as to improve the training quality of business students.

\section{Funding}

This study was supported by the Nanjing University of Finance and Economics 2020 Ideological and Political Demonstration Class Project "Industrial Economics" (Project Number: CQF2020001).

\section{Disclosure statement}

The author declares that there is no conflict of interest.

\section{References}

[1] Yu J, 2020, Research on English Teaching in Universities under the Background of "Internet Plus". Contemporary Education Sciences (11): 97.

[2] Luo M, Li L, 2015, The Innovation of Business Model in Internet Era: from Value Creation Perspective. China Industrial Economics, 322(1): 95-107.

[3] Mcguire T, Manyika J, Chui M, 2012, Why Big Data is the New Competitive Advantage. Ivey Business Journal (7/8): 1-13. 
[4] Shen Q, Shi W, 2019, Innovative Development of Business Vocational Education in China in the Internet Era. Journal of Wuxi Business Vocational and Technical College, 19(01): 1-5.

[5] Qi W, Liu L, 2013, Analysis of Contemporary College Students' Cooperative Consciousness and its Training Methods. Education and Teaching Forum (28): 1-2.

[6] Kong W, 2014, Research on MBA Alumni Tutorial System Based on the Improvement of Comprehensive Quality and Ability. Degree and Graduate Education (03): 18-23. 